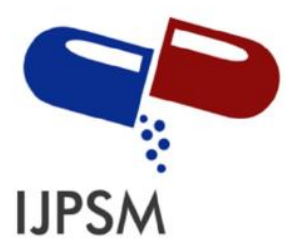

Paul Hassan Ilegbusi et al, Int. Journal of Pharmaceutical Sciences and Medicine (IJPSM), Vol.6 Issue. 6, June- 2021, pg. 64-97

\title{
Knowledge, Attitude and Practice of Women of Childbearing Age towards the Acceptance of Contraceptive Implants in Akungba-Akoko, Ondo State
}

\author{
Paul Hassan Ilegbusi ${ }^{1}$; Michael Olabode Tomori ${ }^{2}$; Bolanle Yemisi Alabi ${ }^{3}$ \\ ${ }^{1}$ Senior Lecturer, Community Health Department, Ondo State College of Health Technology, Akure, Nigeria, \\ E-mail address: princeilegbusi@gmail.com \\ ${ }^{2}$ Strategic Information Lead, APIN Public Health Initiatives, Akure, Ondo Region/Project Supervisor \& Facilitator \\ National Open University, Akure, Ondo State, Nigeria, E-mail address: mtomori@yahoo.com \\ ${ }^{3}$ Lecturer 1, University of Medical Science, Ondo, Ondo State, Nigeria, E-mail address: by.alabi@gmail.com
}

DOI: 10.47760/ijpsm.2021.v06i06.007

\begin{abstract}
Contraceptive implants are progesterone-only contraception that is inserted subdermally. They are readily reversible with a return to fertility within days of removal. NDHS, (2019) recorded that the unmet need for family planning was higher among sexually active unmarried women (48\%) than among currently married women (19\%). The contraceptive prevalence in Nigeria was $16.6 \%$ as against $27 \%$ national target and implants accounts for $3.4 \%$. The aim of the study is to investigate into the knowledge, attitude and practice of women of childbearing age towards the acceptance of contraceptive implants in Akungba-Akoko, Ondo State. A descriptive study was conducted on women of childbearing age (15-49 years) in Akungba-Akoko. Simple random technique was used in selecting the 423 respondents. The consent of the respondents were sought before administering the questionnaires. The data was analysed, using the IBM SPSS Statistics version 27.0.1.0. The study showed that $40.67 \%$ and $55.32 \%$ had secondary and tertiary education respectively. The age of the respondents at first birth was between 15 and 34 years, with the highest between 20-24 years (44.21\%), followed by 15-19 years (21.28\%). 20.33\% were aware of the minimal side effects of contraceptive implants while $79.67 \%$ were not. $46.57 \%$ knew that contraceptive implants are highly effective while $53.19 \%$ did not. $7.57 \%$ knew that fertility would be returned immediately after the removal of contraceptive implants whereas $92.43 \%$ did not know. The study showed that most of the women who are currently using contraceptive implants did not know much about it Akungba-Akoko. The survey also revealed factors influencing the acceptance of contraceptive implants among women. Recommendations were made to improve the knowledge, attitude and practice of women of childbearing age towards the acceptance of contraceptive implants.
\end{abstract}

Keywords: Contraceptive implants; Demand for modern contraceptives; Etonogestrel; Levonorgestrel; Unmet need for family planning. 


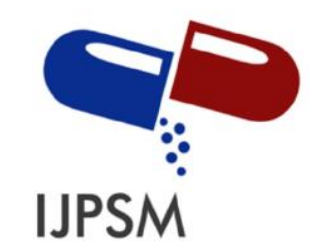

Paul Hassan Ilegbusi et al, Int. Journal of Pharmaceutical Sciences and Medicine (IJPSM), Vol.6 Issue. 6, June- 2021, pg. 64-97

ISSN: 2519-9889

Impact Factor: 3.426

\section{Introduction}

Contraception, according to Kolawole et al. (2018, p. 108-112) is the act of preventing pregnancy by interrupting the chains of events that lead to conception. It is very paramount in reducing the risk of unintended pregnancies and their attendant complications especially because of the strict abortion laws in Nigeria. It has been estimated that of the 210 million pregnancies that occur annually worldwide, about 80 million (38\%) are unplanned, and 46 million (22\%) end in abortion. Unintended unprotected intercourse is the primary cause of unwanted pregnancies, and many women with unwanted pregnancies decide to end them by abortion, which is most unsafe. Wider uptake of long-acting reversible contraceptive (LARC) methods is predicted to scale back the high rate of unintended pregnancy.

LARCs are defined within the UK National Institute for Health and Care Excellence guideline by Mavranezouli, (2008) as contraceptive methods that need administration but once per cycle or month. Included within the category of LARCs are progestin-only contraceptive implants and other methods. Contraceptive implants are progesterone-only contraception that is inserted subdermally. They are readily reversible with a return to fertility within days of removal. Moreover, these contraceptive devices are often safely placed within the immediate postpartum period, ensuring good contraceptive coverage. Irregular bleeding is their common side effect.

World Health Organization (WHO, 2020, p. 50-56) reported that the proportion of women of reproductive age who have their need for family planning satisfied with modern methods between 2010-2019 in Nigeria was 35.6\%. The adolescent birth rate (per 1000 women aged 15-19 years) in Nigeria between 2010-2019 was 106\%. This report is in tandem with the Nigeria Demographic and Health Survey (NDHS) (2019, p. 97-102) which presented that teenage pregnancy is a major health concern because of its association with higher morbidity and mortality for both the mother and the child. Childbearing during adolescence is understood to possess adverse social consequences, particularly regarding educational attainment, as women who become mothers in their teens are more likely to drop out of school. In Nigeria, $19 \%$ of girls age $15-19$ have begun childbearing; $14 \%$ have given birth, and $4 \%$ are pregnant with their first child.

NDHS, (2019, p. 129-162) recorded that the unmet need for family planning was higher among sexually active unmarried women (48\%) than among currently married women (19\%). The total demand for family planning among currently married women was $36 \%$. The survey indicated that the contraceptive prevalence in Nigeria was $16.6 \%$ as against $27 \%$ national target and implants accounts for 3.4\%. It was also indicated in NDHS, (2019, p. 129-162) that Ondo State prevalence of implants among women of reproductive age was $7.8 \%$. Based on the report from Akungba-Akoko Comprehensive Health Centre for 2019, the prevalence of implants was $2.6 \%$, hence, the need to work on this study. 


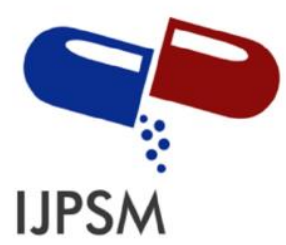

Paul Hassan Ilegbusi et al, Int. Journal of Pharmaceutical Sciences and Medicine (IJPSM), Vol.6 Issue. 6, June- 2021, pg. 64-97

ISSN: 2519-9889

Impact Factor: 3.426

The aim of the study is to investigate into the knowledge, attitude and practice of women of childbearing age towards the acceptance of contraceptive implants in Akungba-Akoko, Ondo State.

The objectives are:

1. To assess the knowledge of women of childbearing age towards the acceptance of contraceptive implants in Akungba-Akoko.

2. To identify factors influencing the acceptance of contraceptive implants among women of childbearing age in Akungba-Akoko.

3. To find out the attitude of women of childbearing age towards contraceptive implants in Akungba-Akoko.

4. To investigate the practice of women of childbearing age towards contraceptive implants in Akungba-Akoko.

\section{Methods}

\subsection{Research Design}

The nature of the study design used for this research was descriptive. This is because it will help to interpret all the conditions which exist in the study, with the use of data that carries psychometric tools and procedures to investigate the knowledge, attitude and practice of women of childbearing age towards the acceptance of contraceptive implants in Akungba-Akoko, Ondo State of Nigeria.

\subsection{Study Area}

Akungba-Akoko was selected for this investigation and was picked among the towns that were having low utilisation of contraceptive implants in Akoko South West Local Government Areat of Ondo State, Nigeria, through balloting. According to the 2006 census, the population of Akungba-Akoko was 15,579 and their major economic activities are farming, teaching, banking and trading. Akungba-Akoko lies on longitude 5'44' east and Latitude 7'28' north of the Equator. It is located on an undulating and rocky terrain. It is bordered to the North by Ikare-Akoko, South by Oba-Akoko, East by Iwaro-Oka Akoko and West by Supare-Akoko. The climate of Akungba-Akoko falls within the tropical region with rainfall which varies from $1100-2000 \mathrm{~mm}$ once a year. The temperature is between $26^{\circ} \mathrm{C}$ and $28^{\circ} \mathrm{C}$. There are alternate wet/raining and dry seasons. Akungba-Akoko is the host community of Adekunle Ajasin University (Ehinmowo \& Eludoyin, 2010, p. 149-154).

\subsection{Study Population}

Women of childbearing age (15-49 years) who were living in Akungba-Akoko were selected for this study in order to investigate their knowledge, attitude and practice towards the acceptance of contraceptive implants. 


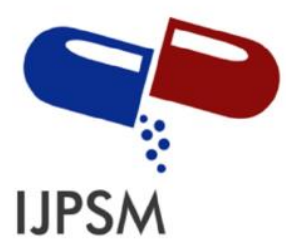

Paul Hassan Ilegbusi et al, Int. Journal of Pharmaceutical Sciences and Medicine (IJPSM), Vol.6 Issue. 6, June- 2021, pg. 64-97

ISSN: 2519-9889

Impact Factor: 3.426

\subsection{Sample Size Determination}

The sample size was determined, using the Cochran's formula for a single population proportion:

$\mathrm{n}_{\mathrm{o}}=\underline{\mathrm{z}^{2} \mathrm{pq}}$

$\mathrm{e}^{2}$

Where:

$\mathrm{z}$ is the confidence level of 1.96 ,

$\mathrm{e}$ is the desired level of precision (i.e. the margin of error, which is 0.05),

$\mathrm{p}$ is the (estimated) proportion of the population of women of childbearing age (which is 0.5 ), and

$\mathrm{q}$ is $1-\mathrm{p}$.

Hence,

$\mathrm{n}=(1.96)^{2} \times 0.5 \times(1-0.5)$

$(0.05)^{2}$

$\mathrm{n}=\underline{3.8416 \times 0.5 \times 0.5}$

0.0025

$\mathrm{n}=\underline{0.9604}$

0.0025

Therefore, $\mathrm{n}=384.16$.

Additional 10\% allowance (non-response) for absenteeism, refusal to participate or incomplete data in the study was considered. Thus, $384.16+38.416=422.58$; (423 approximated). Therefore, 423 women of childbearing age were questioned, using a structured questionnaire. 


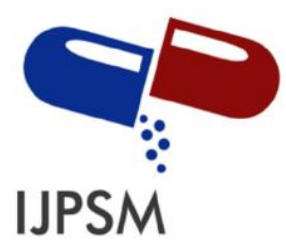

Paul Hassan Ilegbusi et al, Int. Journal of Pharmaceutical Sciences and Medicine (IJPSM), Vol.6 Issue. 6, June- 2021, pg. 64-97

ISSN: 2519-9889

Impact Factor: 3.426

\subsection{Sampling Technique}

The sampling technique that was used for this research was simple random technique, in which the sample was collected based on individual's knowledge and exposure to contraceptive implants. The technique gives every woman of childbearing age an equal chance of being selected. All the quarters in Akungba-Akoko were equally represented in the sample.

\subsection{Study Instrument}

A pre-tested administered questionnaire was used to collect information from the respondents on their knowledge, attitude and practice towards the acceptance of contraceptive implants. The questionnaire comprised four different sections: the socio-demographic characteristics; the level of knowledge towards the acceptance of contraceptive implants; the attitude of women of childbearing towards the acceptance of contraceptive implants; and the practice of women of childbearing age towards the acceptance of contraceptive implants. The questionnaire was translated into Yoruba language, for easy comprehension by the respondents.

\subsection{Reliability and Validity of Measurements or Data}

The quality of data was assured by properly designing and pre-testing of the questionnaire. The questionnaire was reviewed every day and checked for completeness by the investigator, and the necessary feedback was given to data collectors in the next morning before data collection.

The questionnaire was pre-tested in Ikanmu, Oka-Akoko other than the selected study area (in Akungba-Akoko), but has similar socio-demographic characteristics with the study population. Accordingly, it was carried out among 5\% of the total sample size and necessary modifications were made to the questionnaire before actual data collection.

\subsection{Data Collection}

The data was collected through the use of a structured questionnaire. The questionnaire was administered to the respondents and was retrieved after it had been duly responded to. The data was sorted out in order to select the completely filled questionnaires. The data was analysed on International Business Machines Corporation Statistical Package for Social Sciences (IBM SPSS Statistics v.27.0.1.0), using simple percentage with frequency table.

\subsection{Data Analysis}

Data entry and statistical analysis was done using International Business Machines Corporation Statistical Package for Social Sciences (IBM SPSS Statistics) version 27.0.1.0 (IBM Armonk, New York). The data collected using the above mentioned measures were analysed, using frequencies and percentages. Chi square test was used for testing the significance of association at $\mathrm{P}$ value of 0.05 . 


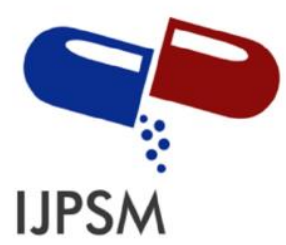

Paul Hassan Ilegbusi et al, Int. Journal of Pharmaceutical Sciences and Medicine (IJPSM), Vol.6 Issue. 6, June- 2021, pg. 64-97

ISSN: 2519-9889

Impact Factor: 3.426

\subsection{Ethical Approval}

Ethical clearance was obtained from the Research Ethics Committee, Ondo State Ministry of Health. Informed consent was obtained from each respondent. Utmost care was taken to take care of privacy and confidentiality.

\section{RESULTS}

Four hundred and twenty-three (423) structured questionnaires were distributed and retrieved completely in Akungba-Akoko, Ondo State of Nigeria. The following are the data collected and interpreted:

\subsection{Socio-demographic Variables of the Respondents}

This section discussed the background information of the respondents and were analysed. The background information of the respondents include the Age-group of the respondents, occupation, marital status, educational system, e.t.c. The variable will be analysed using frequency and percentage distribution.

\section{Age of the Respondents.}

The age-group of women at childbearing age-group were analysed between the ages of 15 - 49 years. It is believed that a lady who is 15 years of age can give birth to a child up to 49 years. Age 49 years is considered as a maximum age-group of childbearing. Therefore, it is important to investigate the knowledge, attitude and practice of women of childbearing age towards the acceptance of contraceptive implants.

Table 1: Age of the Respondents

\begin{tabular}{ccc}
\hline Age of the Respondents & Frequency Distribution & Percentage Distribution \\
\hline $15-19$ years & 25 & 5.91 \\
$20-24$ years & 115 & 27.19 \\
$25-29$ years & 97 & 22.92 \\
$30-34$ years & 65 & 15.37 \\
\hline $35-39$ years & 42 & 9.93 \\
$40-44$ years & 42 & 9.93 \\
$45-49$ years & 37 & 8.75 \\
\hline Total & $\mathbf{4 2 3}$ & $\mathbf{1 0 0 . 0}$
\end{tabular}

Source: Researcher's Field Survey, 2021.

Table 1 shows the number of respondents of women at their child-bearing age. The result shows that $5.91 \%$ of the respondents are between the age of 15 - 19 years; $27.19 \%$ of the respondents are between the age of $20-24$ years; $22.92 \%$ of the respondents are between the age of $25-29$ years; $15.37 \%$ are between the age of $30-34$ years; $9.93 \%$ of the respondents are between the age of 35 - 39 years and $40-44$ years respectively; and $8.75 \%$ of the respondents are between the age of $45-49$ years. This 


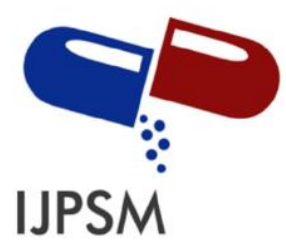

Paul Hassan Ilegbusi et al, Int. Journal of Pharmaceutical Sciences and Medicine (IJPSM), Vol.6 Issue. 6, June- 2021, pg. 64-97

ISSN: 2519-9889

Impact Factor: 3.426

implies that the age-group between 20 - 24 years responded more to the questionnaires than any other age group considered. This might be due to the reason that women tend to give birth to their first child at the age group.

\section{Marital Status of the Respondents}

The marital status of the respondents was analysed using frequency and percentage distribution. In this section, the highest number of respondents is considered and reported accordingly.

Table 2: The Marital Status of the Respondents

\begin{tabular}{ccc}
\hline Marital Status & Frequency Distribution & Percentage Distribution (\%) \\
\hline Single & 89 & 21.04 \\
Married & 313 & 74.00 \\
Divorced & 13 & 3.07 \\
Separated & 8 & 1.89 \\
\hline Total & $\mathbf{4 2 3}$ & $\mathbf{1 0 0 . 0}$ \\
\hline
\end{tabular}

Source: Researcher's Field Survey, 2021.

Table 2 represents the number of people who responded to different marital status. The result of the analysis shows that $74 \%$ of the respondents are married; $21.04 \%$ of them are single; $3.07 \%$ of the respondents are divorced and $1.89 \%$ of the respondents are separated. This implied that most respondents are married and are most likely to know about contraceptive implants, attitude and practice of women of childbearing age towards the acceptance of contraceptive implants even though the least number of respondents are separated. It is most likely people who are separated have wide knowledge about the acceptance of contraceptive implants.

\section{Marriage Type}

This section discusses the type of marriage each of the respondents is involved in. We classified the type of marriage into two parts which are monogamy and polygamy marriage. People who are not married are referred to as "Not applicable" (that is, they are not involved in any of these two types of marriage we considered).

Table 3 Marriage Type

\begin{tabular}{ccc}
\hline Variable & Frequency Distribution & Percentage Distribution (\%) \\
\hline Monogamy & 241 & 56.97 \\
Polygamy & 92 & 21.75 \\
Not Applicable & 90 & 21.28 \\
\hline Total & $\mathbf{4 2 3}$ & $\mathbf{1 0 0 . 0}$
\end{tabular}

Source: Researcher's Field Survey, 2021.

The majority of the respondents are involved in monogamy type of marriage with the frequency and percentage distribution of $241(56.97 \%)$ while $21.75 \%$ of the respondents are involved in polygamy type of marriage and $21.28 \%$ of the respondents are not involved in any of the types of marriage as 


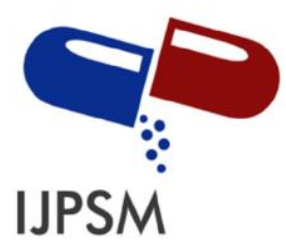

Paul Hassan Ilegbusi et al, Int. Journal of Pharmaceutical Sciences and Medicine (IJPSM), Vol.6 Issue. 6, June- 2021, pg. 64-97

shown in the table above. This means that a larger percentage of the respondents are practising one husband and one wife. That is, they are practising the marriage between two people. Each of the respondents has just one partner.

\section{Educational Status of the respondents}

It is important to know the level of education of each respondent since it contributes more to their knowledge and attitude towards the practice of contraceptive implants. The table below reports the frequency distribution and the percentage distribution of the respondents.

Table 4: Educational Status

\begin{tabular}{ccc}
\hline Variable & Frequency Distribution & Percentage Distribution (\%) \\
\hline Primary & 10 & 2.36 \\
Secondary & 172 & 40.67 \\
Tertiary & 234 & 55.32 \\
None & 7 & 1.65 \\
\hline Total & $\mathbf{4 2 3}$ & $\mathbf{1 0 0 . 0}$ \\
\hline
\end{tabular}

Source: Researcher's Field Survey, 2021.

The table shows the level of education of the respondents. The result shows that 234 respondents have a tertiary level of education with the percentage distribution of 55.32\%, followed by the respondents who have a secondary level of education with the frequency and percentage distribution of 172 (40.67\%); 10 respondents out of the 423 respondents have primary school level of education and 7 of the respondents have none. This means that majority of the respondents are educated and are more likely to know about contraceptive implants. The reasons for the higher number of tertiary levels of education could also be because the questionnaires were distributed among the community of Akungba-Akoko. Also, all level of education from NCE, OND, HND, B.Sc, M.Sc and PhD are classified as a tertiary institution.

\section{Occupation of the Respondents}

The occupations of the respondents are considered at a different level. The frequency and percentage of the occupation were analysed and the categories of variable considered include civil service, farmer, student, trader, artisan and unemployed.

Table 5: Occupation of the Respondents

\begin{tabular}{ccc}
\hline Variables & Frequency Distribution & Percentage Distribution (\%) \\
\hline Civil Service & 83 & 19.62 \\
Farmer & 46 & 10.87 \\
Students & 84 & 19.87
\end{tabular}




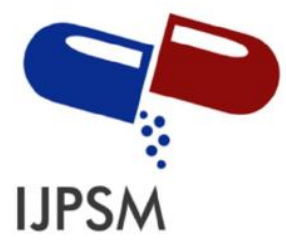

Paul Hassan Ilegbusi et al, Int. Journal of Pharmaceutical Sciences and Medicine (IJPSM), Vol.6 Issue. 6, June- 2021, pg. 64-97

ISSN: 2519-9889

Impact Factor: 3.426

\begin{tabular}{ccc} 
Trader & 136 & 32.15 \\
Artisan & 53 & 12.53 \\
Unemployed & 21 & 4.96 \\
\hline Total & $\mathbf{4 2 3}$ & $\mathbf{1 0 0 . 0}$ \\
\hline
\end{tabular}

Source: Researcher's Field Survey, 2021.

As shown in Table 5, a larger percentage of the respondents are traders with the frequency and percentage distribution of 136 (32.15\%); followed by $19.87 \%$ of the respondents who responds to students, $19.62 \%$ of the respondents respond to civil service, $12.53 \%$ of them respond to artisan; $10.87 \%$ of them are farmer and $4.96 \%$ of them are unemployed. This implies that the majority of the respondents are traders. This means that the respondents are into buying and selling goods and services.

\section{Religion of the Respondents}

Religion is classified into three main part which includes Christianity, Islam and traditionalist. This religion can affect the use of contraceptive, the knowledge of the use and can also affect the knowledge about the contraceptive implants.

Table 6: Religion of the Respondents

\begin{tabular}{ccc}
\hline Religion & Frequency Distribution & Percentage Distribution \\
\hline Christianity & 299 & 70.69 \\
Islam & 110 & 26.00 \\
Traditionalist & 9 & 2.13 \\
None & 5 & 1.18 \\
\hline Total & $\mathbf{4 2 3}$ & $\mathbf{1 0 0 . 0}$ \\
\hline
\end{tabular}

Source: Researcher's Field Survey, 2021.

Table 6 shows that 299 out of 423 respondents are Christian with a percentage distribution of $70.69 \%$, it was also shown that $26 \%$ of the respondents are Muslim (Islam), $2.13 \%$ of them are a traditionalist and $1.18 \%$ of the respondents do not belong to any of the religion. This implies that the women who are interviewed at the point of receiving the questionnaires are Christian.

\section{The age of the respondents at first birth}

The age of women when giving birth to their first child was reported. The age-group was considered between 15 years until 34 years. 


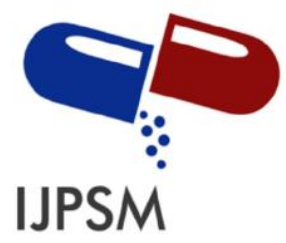

Paul Hassan Ilegbusi et al, Int. Journal of Pharmaceutical Sciences and Medicine (IJPSM), Vol.6 Issue. 6, June- 2021, pg. 64-97

Table 7: Age at first birth

\begin{tabular}{ccc}
\hline Variable & Frequency distribution & Percentage Distribution $\mathbf{( \% )}$ \\
\hline $15-19$ years & 90 & 21.28 \\
$20-24$ years & 187 & 44.21 \\
$25-29$ years & 81 & 19.15 \\
$30-34$ years & 11 & 2.60 \\
$35-39$ years & 0 & 0.0 \\
$40-44$ years & 0 & 0.0 \\
$45-49$ years & 0 & 0.0 \\
Not applicable & 54 & 12.77 \\
\hline Total & $\mathbf{4 2 3}$ & $\mathbf{1 0 0 . 0}$ \\
\hline
\end{tabular}

Source: Researcher's Field Survey, 2021.

The table shows that $44.21 \%$ of the respondents give birth to their first child between the age of $20-24$ years; followed by $21.28 \%$ of the respondents who gave birth between the age of 15 - 19 years; $19.15 \%$ of the respondents gave birth between the age-group of $25-29$ years and $2.60 \%$ of them respond that they gave birth between 30 - 34 years. Meanwhile, $12.77 \%$ of 423 respondents say the age at first birth does not apply to them with no respondents to $35-39$ years, 40 - 44 years, and $45-49$ years. This means that women between the age group of $20-24$ years are more likely to give birth to their first child.

\section{Number of live-born children}

As at the time of collecting this data, information on the number of live-born of the women was collected. We defined a live-born as any child who shows signs of life after birth or a child born alive after cutting the umbilical cord.

The report was collected on the number of births the respondents have. We classified the number of live births into different categories which include first live-birth, second live-birth, third live-birth, fourth live-birth and number of birth greater than 4 .

Table 8: Number of Live-born children

\begin{tabular}{ccc}
\hline Variable & $\begin{array}{c}\text { Frequency } \\
\text { Distribution }\end{array}$ & Percentage Distribution (\%) \\
\hline None & 54 & 12.77 \\
1 & 64 & 15.13 \\
2 & 115 & 27.19 \\
3 & 119 & 28.13
\end{tabular}




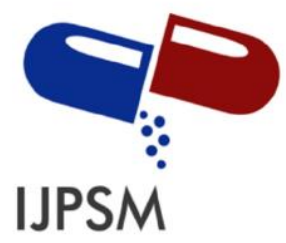

Paul Hassan Ilegbusi et al, Int. Journal of Pharmaceutical Sciences and Medicine (IJPSM), Vol.6 Issue. 6, June- 2021, pg. 64-97

\begin{tabular}{ccc}
4 & 50 & 11.8 \\
More than 4 & 21 & 4.96 \\
\hline Total & $\mathbf{4 2 3}$ & $\mathbf{1 0 0 . 0}$ \\
\hline
\end{tabular}

Source: Researcher's Field Survey, 2021.

The table shows that the majority of the respondents had three live-born with the frequency and percentage distribution of 119 (28.13\%); followed by the respondents who have 2 live-born children with the frequency and percentage distribution of 115 (27.19\%); $15.13 \%$ of the respondents have 1 child; $12.77 \%$ of the respondents have none; $11.8 \%$ of the respondents have 4 live-born children and $4.96 \%$ of them have more than 4 live-born children. This means a minimal number of respondents do not have a live-born child.

\subsection{Knowledge of women of childbearing age towards the acceptance of contraceptive implants.}

\section{Contraceptive Implants}

This section tends to know whether the respondents have heard about contraceptive implants before. A question was asked whether the respondents have heard about contraceptive implant before?

Table 9: Heard about contraceptive Implant before?

\begin{tabular}{ccc}
\hline Variable & Frequency distribution & Percentage Distribution (\%) \\
\hline Yes & 278 & 65.72 \\
No & 145 & 34.28 \\
\hline Total & $\mathbf{4 2 3}$ & $\mathbf{1 0 0 . 0}$ \\
\hline
\end{tabular}

Source: Researcher's Field survey, 2021

As shown in Table 9 above, $65.72 \%$ of the respondents have heard about the implant of contraceptive before while $34.28 \%$ have not heard about contraceptive implant before. This means that majority of the women between $15-49$ years have one way or the other heard about the contraceptive implant.

\section{Source of Information}

Information is gathered from a different source. It is noted that respondents are aware of the contraceptive implant before. It is necessary to identify where that information is been gathered. Therefore, table 4.10 shows the frequency and percentage distribution of where information about contraceptive implant are been gathered. 


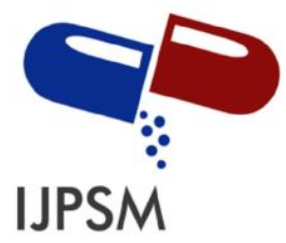

Paul Hassan llegbusi et al, Int. Journal of Pharmaceutical Sciences and Medicine (IJPSM), Vol.6 Issue. 6, June- 2021, pg. 64-97

Table 10: $\quad$ Source of Information

\begin{tabular}{ccc}
\hline Variable & $\begin{array}{c}\text { Frequency } \\
\text { Distribution }\end{array}$ & Percentage Distribution (\%) \\
\hline Health facility & 198 & 46.81 \\
Friends & 23 & 5.44 \\
Internet & 11 & 2.60 \\
Radio / Television & 33 & 7.80 \\
Newspaper / Magazine & 13 & 3.07 \\
Missing values & 145 & 34.28 \\
\hline Total & $\mathbf{4 2 3}$ & $\mathbf{1 0 0 . 0}$ \\
\hline
\end{tabular}

Source: Researcher's Field Survey, 2021.

The table shows that 198 respondents $(46.8 \%)$ heard from the health facility, 23 respondents $(5.4 \%)$ heard from friends, 11 respondents $(2.6 \%)$ got the information from the internet, 33 respondents $(7.8 \%)$ heard from radio and television, 13 respondents (3.1\%) read from newspaper or magazine, and 145 $(34.3 \%)$ was a non-response. Though all the respondents heard from one source or the other, this also shows that majority of the respondents heard information about contraceptive implants from health facilities.

\section{Benefit of Contraceptive Implants}

The respondents were asked whether they know the benefit of contraceptive implants. The response was analysed using frequency and percentage distribution. The result of the analysis was shown in Table 11 below.

Table 11: $\quad$ Contraceptive Implants have a lot of benefits

\begin{tabular}{ccc}
\hline Variable & Frequency distribution & Percentage Distribution (\%) \\
\hline Yes & 222 & 52.48 \\
No & 201 & 47.52 \\
\hline Total & $\mathbf{4 2 3}$ & $\mathbf{1 0 0 . 0}$ \\
\hline
\end{tabular}

Source: Researcher's Field Survey, 2021.

Response in Table 11 shows that $52.48 \%$ of the respondents know a lot of benefit of contraceptive implants since they respond to "Yes" while $47.52 \%$ of the respondents responded to "No". This implies that most respondents know the benefits of contraceptive implants. 


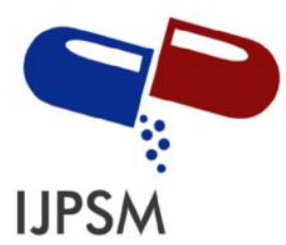

Paul Hassan Ilegbusi et al, Int. Journal of Pharmaceutical Sciences and Medicine (IJPSM), Vol.6 Issue. 6, June- 2021, pg. 64-97

ISSN: 2519-9889

Impact Factor: 3.426

\section{Awareness of the minimal side effects of contraceptive implants}

The section tends to ask whether women between 15 - 49 years of age are aware of the side effects of contraceptive implants. The result was analysed using frequency and percentage distribution.

Table 12: Awareness of the minimal side effects of contraceptive implants

\begin{tabular}{ccc}
\hline Variable & Frequency Distribution & Percentage Distribution (\%) \\
\hline Yes & 86 & 20.33 \\
No & 337 & 79.67 \\
\hline Total & $\mathbf{4 2 3}$ & $\mathbf{1 0 0 . 0}$ \\
\hline
\end{tabular}

Source: Researcher's Field Survey, 2021.

As shown in Table 12, the result of the analysis shows that a larger percentage of the respondents are not aware of the minimal side effects of contraceptive implants with the frequency and percentage distribution of 337 (79.67\%) while the respondents who said they are aware of the minimal side effect of contraceptive implants are 86 out of 423 total respondents.

\section{Safety of contraceptive implants}

In this section, the awareness of contraceptive implants safety for every woman of childbearing age is considered. The knowledge of every woman is considered using a 'yes' or 'no' question.

Table 13: Awareness on the safety of contraceptive implants

\begin{tabular}{ccc}
\hline Variable & Frequency Distribution & Percentage Distribution (\%) \\
\hline Yes & 235 & 55.56 \\
No & 188 & 44.44 \\
\hline Total & $\mathbf{4 2 3}$ & $\mathbf{1 0 0 . 0}$ \\
\hline
\end{tabular}

Source: Researcher's Field Survey, 2021.

It is shown from Table 13 shows that $55.56 \%$ of the respondents are aware of the safety of contraceptive implants with the frequency distribution of 235 out of 423 respondents. It also shows that $44.44 \%$ of the respondents respond that they are not aware whether the contraceptive implant is safe for every woman of childbearing age.

\section{Effect of Contraceptive Implants}

The effect of contraceptive implants is analysed using frequency and percentage distribution. This question was asked whether contraceptive implants are highly effective or not. 


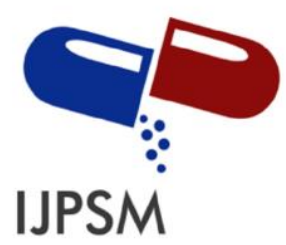

Paul Hassan Ilegbusi et al, Int. Journal of Pharmaceutical Sciences and Medicine (IJPSM), Vol.6 Issue. 6, June- 2021, pg. 64-97

Table 14: $\quad$ Effect of contraceptive implants

\begin{tabular}{ccc}
\hline Variable & Frequency Distribution & Percentage Distribution (\%) \\
\hline Yes & 197 & 46.57 \\
No & 225 & 53.19 \\
Missing Value & 1 & 0.24 \\
\hline Total & $\mathbf{4 2 3}$ & $\mathbf{1 0 0 . 0}$ \\
\hline
\end{tabular}

Source: Researcher's Field Survey, 2021.

Most respondents respond that they are not aware of the high effect of contraceptive implants since they respond to No with the frequency and percentage distribution of $225(53.19 \%)$ while $46.57 \%$ out of 423 respondents say they are aware of the high effect of contraceptive implants. The result shows a missing value of 1 respondent which shows that $0.24 \%$ of the respondents do not respond to either they are aware or not about the high effectiveness of the contraceptive implants.

\section{Fertility returned after the removal of contraceptive implants}

The table below shows whether the respondents are aware that fertility is quickly returned after the removal of contraceptive implants using frequency and percentage distribution.

Table 15: Fertility returned after the removal of contraceptive implants

\begin{tabular}{ccc}
\hline Variable & Frequency Distribution & Percentage Distribution (\%) \\
\hline Yes & 32 & 7.57 \\
No & 391 & 92.43 \\
\hline Total & $\mathbf{4 2 3}$ & $\mathbf{1 0 0 . 0}$ \\
\hline
\end{tabular}

Source: Researcher's Field Survey, 2021.

As shown in Table 15, a question was asked whether the respondents are aware whether the fertility is quickly returned after the removal of contraceptive implants. It is shown from the above that $92.43 \%$ of the respondents are not aware that their fertility is returned immediately after they remove contraceptive implants with the frequency distribution of 391. Also, $7.57 \%$ of the respondents show that they are aware that their fertility is returned immediately after they remove the contraceptive implants.

\section{Hypothesis Testing}

The socio-demographic variables of the respondents would be examined with the use of contraceptive implants. This section would be analysed using cross-tabulation and chi-square distribution. The cross-tabulation would help us to determine each socio-demographic variable either to agree with the use of contraceptive implants or not. Also, the chi-square distribution is a non-parametric test which is 


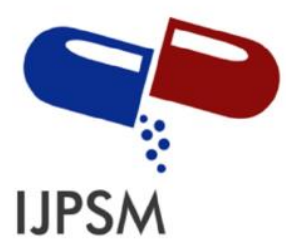

Paul Hassan Ilegbusi et al, Int. Journal of Pharmaceutical Sciences and Medicine (IJPSM), Vol.6 Issue. 6, June- 2021, pg. 64-97

used to determine whether there would be an association between each of the socio-demographic variable and the use of contraceptive implants.

\section{Hypothesis Testing on Age and current use of contraceptive implants.}

In this section, we intend to know the age-group who are currently on the use of contraceptive. This would be analysis using cross-tabulation which would present the frequency distribution of all the categories of age-group who responded to either "yes" or "no" on the current use of contraceptive implants. The association between the variables would be determined using chi-square distribution.

\section{Cross-tabulation on age and current use of contraceptive implants.}

The frequency distribution of all the childbearing age who are currently using contraceptive implants is explained in the table below.

Table 16: Age and current use of contraceptive implants

\begin{tabular}{cccc}
\hline \multicolumn{4}{c}{ Are you on contraceptive implants now? } \\
\hline Age & Yes & No & Total \\
\hline $15-19$ years & 15 & 10 & 25 \\
$20-24$ years & 67 & 48 & 115 \\
$25-29$ years & 67 & 30 & 97 \\
$30-34$ years & 49 & 16 & 65 \\
$35-39$ years & 33 & 9 & 42 \\
$40-44$ years & 24 & 18 & 42 \\
$45-49$ years & 23 & 14 & 37 \\
\hline Total & $\mathbf{2 7 8}$ & $\mathbf{1 4 5}$ & $\mathbf{4 2 3}$ \\
\hline
\end{tabular}

Source: Researcher's Field Survey, 2021.

All the categories of the childbearing age of women between 15 to 49 years show that all the age-group are currently using contraceptive implants. The result is shown in Table 16 further explained that 278 respondents of the 423 total respondents are using contraceptive implants at the time of reporting the questionnaires while the total of 145 respondents are not using a contraceptive implants at that time. The respondents who are not using might be because they are either pregnant or they just gave birth to a child or they are still single.

\section{Chi-square distribution on age and current use of contraceptive implants.}




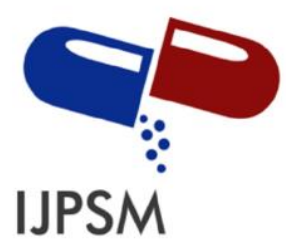

Paul Hassan Ilegbusi et al, Int. Journal of Pharmaceutical Sciences and Medicine (IJPSM), Vol.6 Issue. 6, June- 2021, pg. 64-97

ISSN: 2519-9889

Impact Factor: 3.426

The null hypothesis states that there is no association between age and the current use of contraceptive implants. Then the decision rule stated that if P-value $<0.05$, reject the null hypothesis, otherwise do not reject the null hypothesis.

Table 17: Chi-square test of Age and current use of contraceptive implants.

\begin{tabular}{llll}
\hline & Value & Df & P-value \\
\hline Pearson Chi-square & 11.040 & 6 & 0.087 \\
Likelihood Ratio & 11.313 & 6 & 0.079 \\
Linear-by-Linear & 0.544 & 1 & 0.461 \\
Association & & & \\
\hline
\end{tabular}

Source: Researcher's Field Survey, 2021.

The null hypothesis is not rejected since the probability value of the linear by linear association shows a P-value $(0.461)>0.05$. This means that there is no association between childbearing age and the current use of contraceptive implants. It implies that age does not have a significant influence or does not affect the use of contraceptive. As at the time of reporting, it further explained that any categories of childbearing age can use contraceptive implants. Moreover, the Pearson chi-square distribution shows that a rejection of the null hypothesis which means that there is no evidence of a linear association between age and the use of contraceptive implants.

Educational Status and current use of contraceptive implants.

The educational status with the current use of contraceptive implants is also analysed using cross-tabulation of the frequency distribution of the respondents and also the association between the variables.

Crosstab on educational Status and current use of contraceptive implants.

The frequency distribution of the respondents who responded to any of the educational status as well as either yes or no to the current use of a contraceptive implant is shown in the table below.

Table 18: Educational status and current use of contraceptive implants

Are you on contraceptive implants now?

\begin{tabular}{cccc}
\hline Educational Status & Yes & No & Total \\
\hline Primary & 9 & 1 & 10 \\
Secondary & 126 & 46 & 172 \\
Tertiary & 142 & 92 & 234 \\
None & 1 & 6 & 7 \\
\hline Total & $\mathbf{2 7 8}$ & $\mathbf{1 4 5}$ & $\mathbf{4 2 3}$ \\
\hline
\end{tabular}




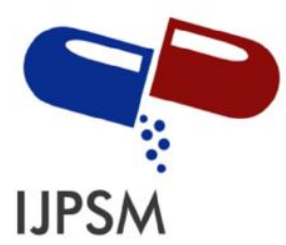

Paul Hassan Ilegbusi et al, Int. Journal of Pharmaceutical Sciences and Medicine (IJPSM), Vol.6 Issue. 6, June- 2021, pg. 64-97

ISSN: 2519-9889

Impact Factor: 3.426

Source: Researcher's Field Survey, 2021.

Based on the level of education, the result shows that respondents who have tertiary education are currently using contraceptive implants as at the time of reporting with the frequency distribution of 142 while 92 respondents of tertiary education say they are not using contraceptive implants as at the time of reporting; 126 respondents of the secondary educational system say they are using it but 46 say they are not using; 9 respondents of the primary school say they are using while 1 say they are not using. Moreover, for none educational system, 6 respondents say no to contraceptive implant and 1 respondent says "yes".

\section{Chi-square distribution on educational Status and current use of contraceptive implants.}

The null hypothesis states that education is not a factor for accepting the use of contraceptive implants.

Decision rule: If probability value (p-value) $<\alpha$, where $\alpha$ is the level of significance and it is considered at $5 \%$ level of significance, reject the null hypothesis, otherwise, do not reject.

Table 19: Chi-square test of educational status and current use of contraceptive implants

\begin{tabular}{llll}
\hline & Value & Df & P-value \\
\hline Pearson Chi-square & 17.807 & 3 & 0.000 \\
Likelihood Ratio & 18.237 & 3 & 0.000 \\
Linear-by-Linear & 14.708 & 1 & 0.000 \\
Association & & & \\
\hline
\end{tabular}

Source: Researcher's Field Survey, 2021.

The null hypothesis was rejected at $\mathrm{P}$-value $<0.05$. This proves that there is an association between educational status and the current use of contraceptive implants. The result also shows the goodness of fit measured by the Pearson chi-square distribution test, it shows that there is evidence of a linear association between educational status and current use of contraceptive implants.

\section{Cross tab on Age at first birth and current use of contraceptive implants}

The frequency distribution of the categories of all age-group and at the same time who say whether yes or no to the current use of contraceptive implants is shown in the table below.

Table 20: Cross tab on Age at first birth and current use of contraceptive implants

\begin{tabular}{cccc}
\hline Age at first birth & Yes & No & Total \\
\hline
\end{tabular}




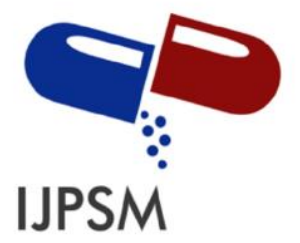

Paul Hassan Ilegbusi et al, Int. Journal of Pharmaceutical Sciences and Medicine (IJPSM), Vol.6 Issue. 6, June- 2021, pg. 64-97

ISSN: 2519-9889

Impact Factor: 3.426

\begin{tabular}{cccc}
\hline $15-19$ years & 69 & 21 & 90 \\
$20-24$ years & 121 & 66 & 187 \\
$25-29$ years & 55 & 26 & 81 \\
$30-34$ years & 8 & 3 & 11 \\
Not applicable & 25 & 29 & 54 \\
\hline Total & $\mathbf{2 7 8}$ & $\mathbf{1 4 5}$ & $\mathbf{4 2 3}$ \\
\hline
\end{tabular}

Source: Researcher's Field Survey, 2021.

The majority of all categories of the age group who has given birth to their first child say they are currently using contraceptive implants. The age at first birth whose number of yes is higher than no include $15-19$ years, 20 - 24 years, $25-29$ years, and $30-34$ years. Twenty-five (25) respondents of people who have not given birth say they use contraceptive implants and 29 respondents say they do not use contraceptive implants.

\section{Chi-square distribution test on Age at first birth and current use of contraceptive implants.}

An association between the age at first birth and the use of contraceptive implants is established using the chi-square distribution test. The null hypothesis states that there is no association between the age at first birth and the current use of contraceptive implants. The decision is if P-value $<0.05$, reject the null hypothesis, otherwise do not reject the null hypothesis.

Table 21: Chi-square test of age at first birth and current use of contraceptive implants

\begin{tabular}{llll}
\hline & Value & Df & P-value \\
\hline Pearson Chi-square & 14.327 & 4 & 0.006 \\
Likelihood Ratio & 14.131 & 4 & 0.007 \\
Linear-by-Linear & 11.308 & 1 & 0.000 \\
Association & & &
\end{tabular}

Source: Researcher's Field Survey, 2021.

The association between the age at first birth and use of contraceptive implants is established since the P-value $<0.05$ (5\% level of significance). It is however, important to note that age at first birth influences the use of contraceptive implants. There is evidence of a linear relationship between the variables with the $\mathrm{p}$-value $(0.006)<0.05$.

\subsection{Attitude of women of childbearing age towards the acceptance of contraceptive implants.}




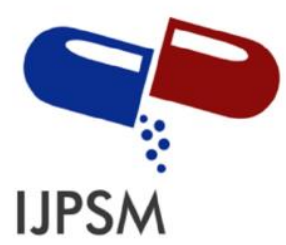

Paul Hassan Ilegbusi et al, Int. Journal of Pharmaceutical Sciences and Medicine (IJPSM), Vol.6 Issue. 6, June- 2021, pg. 64-97

This section would study the behaviour of women between the age of 15 - 49 years and who discussed their acceptance of the use of contraceptive implants. Frequency distribution, percentage distribution and multiple response analysis are used to analyse each question.

\section{Importance of contraceptive implants to family planning}

Contraceptive implants serve as one of the most cost-effective methods of family planning. The section uses frequency and percentage distribution to ascertain the mind of each respondent.

Table 21: Contraceptive implants as a cost-effective method for family planning

\begin{tabular}{ccc}
\hline Variable & Frequency Distribution & Percentage Distribution \\
\hline Yes & 168 & $39.70 \%$ \\
No & 255 & $60.30 \%$ \\
\hline Total & $\mathbf{4 2 3}$ & $\mathbf{1 0 0 . 0}$ \\
\hline
\end{tabular}

Source: Researcher's Field Survey, 2021.

As shown in Table 21, the result shows that $60.30 \%$ of the respondents do not think that the contraceptive implant is the most cost-effective method of family planning. Further analysis shows that $39.7 \%$ of the respondents believe that contraceptive implants are the most cost-effective method of family planning.

\section{Importance of contraceptive implants to couples}

This section tends to know whether the use of contraceptive implants brings harmony between couples.

Table 22: Contraceptive Implants to Couples

\begin{tabular}{ccc}
\hline Variable & Frequency Distribution & Percentage Distribution \\
\hline Yes & 262 & $61.90 \%$ \\
No & 161 & $38.1 \%$ \\
\hline Total & $\mathbf{4 2 3}$ & $\mathbf{1 0 0 . 0}$ \\
\hline
\end{tabular}

Source: Researcher's Field Survey, 2021.

It is observed that the use of contraceptive implants brings harmony among couples with the majority of the respondents responding to "yes" with the frequency and percentage distribution of $61.90 \%$. Also, 161 respondents out of 423 respondents say that contraceptive implants do not bring harmony among couples. This might be because the number of live-born children the couples want to have including the distancing of their children was able to be attained through the use of contraceptive implants.

\section{Reasons women are not interested in contraceptive implants.}

It is observed that some women might not be interested in the use of contraceptive implants. Some of the reasons which might cause why they are not interested are listed below. The respondents are (C) 2021, IJPSM All Rights Reserved, www.ijpsm.com 


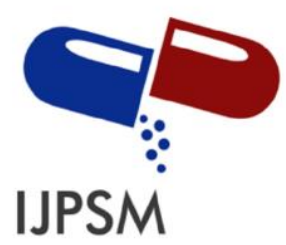

Paul Hassan Ilegbusi et al, Int. Journal of Pharmaceutical Sciences and Medicine (IJPSM), Vol.6 Issue. 6, June- 2021, pg. 64-97

allowed to pick the likely reason they feel it might cause why they are not interested in contraceptive implants.

Table 23: $\quad$ Reasons women are not interested in contraceptive implants.

\begin{tabular}{ccc}
\hline Reasons & $\begin{array}{c}\text { Frequency Distribution } \\
(\mathbf{N})\end{array}$ & $\begin{array}{c}\text { Percentage } \\
\text { Distribution }(\boldsymbol{\%})\end{array}$ \\
\hline It diminishes sexual pleasure & 81 & 19.1 \\
It encourages promiscuity & 71 & 16.8 \\
Fear of side effects & 136 & 32.2 \\
Contraceptive failure & 20 & 4.7 \\
Lack of interest & 11 & 2.6 \\
Lack of regular sex & 14 & 3.3 \\
Husband's refusal & 19 & 4.5 \\
Expectant of becoming pregnant & 35 & 8.3 \\
Lack of information & 36 & 8.5 \\
\hline
\end{tabular}

Source: Researcher's Field Survey, 2021.

The table shows 81 respondents $(19.1 \%)$ indicate that it diminishes sexual pleasure, 71 respondents $(16.8 \%)$ indicate that it encourages promiscuity, 136 respondents $(32.2 \%)$ indicate fear of side effects, 20 respondents $(4.7 \%)$ indicate contraceptive failure, 11 respondents $(2.6 \%)$ indicate lack of interest, 14 respondents (3.3\%) indicate lack of regular sex, 19 respondents $(4.5 \%)$ indicate husband's refusal, 35 respondents $(8.3 \%)$ indicate expectant of becoming pregnant, and 36 respondents $(8.5 \%)$ indicate lack of information. This proves that the majority of the respondents are afraid because of the side effects that might occur after the use of contraceptive implants.

Thought of religion on contraceptive implants.

In this section, we intend to know whether religion forbid the use of contraceptive implants.

Table 24: $\quad$ Thought of religion on contraceptive implants.

\begin{tabular}{ccc}
\hline Variable & Frequency Distribution & Percentage distribution \\
\hline Yes & 216 & $51.1 \%$ \\
No & 207 & $48.9 \%$ \\
\hline Total & $\mathbf{4 2 3}$ & $\mathbf{1 0 0 . 0}$ \\
\hline
\end{tabular}

Source: Researcher's Field Survey, 2021.

A larger percentage of the respondents say that religion forbid the use of contraceptive implants with the frequency and percentage distribution of $216(51.1 \%)$ while $48.9 \%$ of the respondents say that religion does not forbid the use of contraceptive implants. 


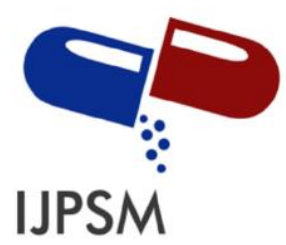

Paul Hassan Ilegbusi et al, Int. Journal of Pharmaceutical Sciences and Medicine (IJPSM), Vol.6 Issue. 6, June- 2021, pg. 64-97

\section{Culture and contraceptive implants}

Frequency and percentage distribution on respondents thought on the reason why culture is against contraceptive implants is analysed in Table 25 .

Table 25: Culture and contraceptive implants

\begin{tabular}{ccc}
\hline Variable & Frequency Distribution & Percentage Distribution \\
\hline Yes & 135 & $31.9 \%$ \\
No & 288 & $68.1 \%$ \\
\hline Total & $\mathbf{4 2 3}$ & $\mathbf{1 0 0 . 0}$ \\
\hline
\end{tabular}

Source: Researcher's Field Survey, 2021.

Respondents believe that culture is not against the use of contraceptive implants since it has a higher percentage distribution of $68.1 \% .31 .9 \%$ of the respondents say culture is against contraceptive implants.

3.3 Practice of women of childbearing age towards the acceptance of contraceptive implants.

Reason for choosing contraceptive implants

Table 26 shows the frequency and percentage distribution of the reasons why respondents choose contraceptive implants.

Table 26: Reasons for choosing contraceptive implants

\begin{tabular}{ccc}
\hline Variable & Frequency Distribution & Percentage Distribution \\
\hline It is convenient & 52 & $12.3 \%$ \\
It is safe & 127 & $30.0 \%$ \\
It is highly effective & 99 & $23.4 \%$ \\
Missing value & 145 & $34.3 \%$ \\
\hline Total & $\mathbf{4 2 3}$ & $\mathbf{1 0 0 . 0}$ \\
\hline
\end{tabular}

Source: Researcher's Field Survey, 2021.

The respondents said the reason why they choose contraceptive implants is because it is safe to use. This is considered because it has the highest frequency distribution of 127 and the percentage distribution of 30.0\%; followed by the respondents who say contraceptive implants are highly effective and $12.3 \%$ say that contraceptive implants are convenient. Though, the response shows that 145 respondents do not respond to this question.

Reasons for not accepting contraceptive implants. 


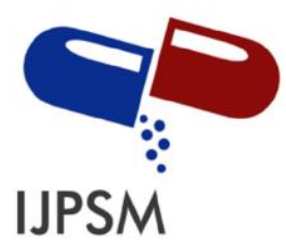

Paul Hassan Ilegbusi et al, Int. Journal of Pharmaceutical Sciences and Medicine (IJPSM), Vol.6 Issue. 6, June- 2021, pg. 64-97

ISSN: 2519-9889

Impact Factor: 3.426

Possible reasons why people do not accept contraceptive implants are listed in Table 27 below. This section tends to know the reasons for not accepting contraceptive implants using the frequency and percentage distribution.

Table 27: Reasons for not accepting contraceptive implants.

\begin{tabular}{ccc}
\hline Variable & Frequency Distribution & Percentage Distribution \\
\hline Fear of side effects & 53 & $12.5 \%$ \\
Religion influence & 7 & $1.7 \%$ \\
Husband's refusal & 17 & $4.0 \%$ \\
\hline Lack of interest & 46 & $10.9 \%$ \\
Contraceptive Failure & 6 & $1.4 \%$ \\
It diminishes sexual pleasure & 3 & $0.7 \%$ \\
Lack of regular sex & 5 & $1.2 \%$ \\
Lack of information & 8 & $1.9 \%$ \\
Missing value & 278 & $65.7 \%$ \\
\hline
\end{tabular}

Source: Researcher's Field Survey, 2021.

The table shows 53 respondents $(12.5 \%)$ indicated fear of side effects, 7 respondents $(1.7 \%)$ indicate religious influence, 17 respondents (4\%) said husband's refusal, 46 respondents (10.9\%) indicated lack of interest, 6 respondents (1.4\%) said contraceptive failure, 3 respondents $(0.7 \%)$ said it diminishes sexual pleasure, 5 respondents $(1.2 \%)$ indicated lack of regular sex, 8 respondents $(1.9 \%)$ indicated lack of information, and 278 (65.7\%) are non-response. This implies that the respondents are afraid of the side effect of using contraceptive implants.

\section{Duration for using contraceptive implants}

The question was asked on the number of years the respondents have been using contraceptive implants using the frequency and percentage distribution shown in Table 28.

Table 28: Duration for using contraceptive implants

\begin{tabular}{ccc}
\hline Variable & $\begin{array}{c}\text { Frequency } \\
\text { Distribution }\end{array}$ & Percentage Distribution \\
\hline$<1$ year & 81 & $19.1 \%$ \\
Between $1-3$ years & 155 & $36.6 \%$ \\
$>$ 3 years & 42 & $9.9 \%$ \\
Missing value & 145 & $34.3 \%$ \\
\hline Total & $\mathbf{4 2 3}$ & $\mathbf{1 0 0 . 0}$ \\
\hline
\end{tabular}

Source: Researcher's Field Survey, 2021. 


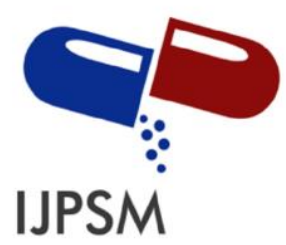

Paul Hassan Ilegbusi et al, Int. Journal of Pharmaceutical Sciences and Medicine (IJPSM), Vol.6 Issue. 6, June- 2021, pg. 64-97

The table shows 81 respondents $(19.1 \%)$ are less than 1 year, 155 respondents $(36.6 \%)$ are between 1 and 3 years, 42 respondents $(9.9 \%)$ are more than 3 years, and $145(34.3 \%)$ are non-response. The result shows that $36.6 \%$ of the total respondents who have been using contraceptive implants have been using them for between 1 to 3 years.

\section{Future Interest}

The interest of the respondents to know whether they would use contraceptive implants in the future was ascertained using frequency and percentage distribution.

Table 29: $\quad$ Future interest in the use of contraceptive implants

\begin{tabular}{ccc}
\hline Variable & $\begin{array}{c}\text { Frequency } \\
\text { Distribution }\end{array}$ & Percentage Distribution \\
\hline Yes & 63 & $14.9 \%$ \\
No & 80 & $18.9 \%$ \\
Missing value & 280 & $66.2 \%$ \\
\hline Total & $\mathbf{4 2 3}$ & $\mathbf{1 0 0 . 0}$ \\
\hline
\end{tabular}

Source: Researcher's Field Survey, 2021.

The total non-response is higher than the response. It is observed that $18.9 \%$ say that they would not go for contraceptive implants in the future while $14.9 \%$ of the respondents say they would have the interest to go contraceptive implants in the future.

\section{Experience of side effects from contraceptive implants before}

We intend to know whether most of the respondents have been having side effect before this data was gathered. This leads to the reason why this aspect of the question was asked. The result from Table 30 shows the frequency and percentage distribution of the respondents who has one way or the other feel any side effect of contraceptive implants before.

Table 30: Respondents' experience of side effects from contraceptive implant before.

\begin{tabular}{ccc}
\hline Variable & Frequency Distribution & Percentage Distribution \\
\hline Yes & 215 & $50.8 \%$ \\
No & 205 & $48.5 \%$ \\
Missing value & 3 & $0.7 \%$ \\
\hline Total & $\mathbf{4 2 3}$ & $\mathbf{1 0 0 . 0}$ \\
\hline
\end{tabular}

Source: Researcher's Field Survey, 2021. 


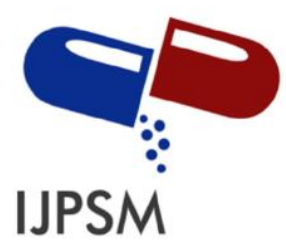

Paul Hassan Ilegbusi et al, Int. Journal of Pharmaceutical Sciences and Medicine (IJPSM), Vol.6 Issue. 6, June- 2021, pg. 64-97

Table 30 shows that respondents have one way or other experience the side effect of contraceptive implants since the percentage of people who responded to yes is $50.8 \%$ while the percentage of people who say no is $48.5 \%$. Meanwhile, $0.7 \%$ of the respondents do not respond to the questionnaire.

\section{Willingness to continue using the contraceptive implants despite side effects.}

In this section intend to know whether the respondent would continue to use contraceptive despite the side effect the implants is having. The table below shows the response of the respondents on their response.

Table 31: Willingness to continue using contraceptive implants despite side effects.

\begin{tabular}{ccc}
\hline Variable & Frequency Distribution & Percentage Distribution \\
\hline Yes & 145 & $34.3 \%$ \\
No & 77 & $18.2 \%$ \\
Missing Value & 210 & $47.5 \%$ \\
\hline Total & $\mathbf{4 2 3}$ & $\mathbf{1 0 0 . 0}$ \\
\hline
\end{tabular}

Source: Researcher's field Survey, 2021.

The result shows that there $34.3 \%$ of the respondents would continue using the contraceptive despite the side effect the drug is having. Also, $18.2 \%$ of the respondents say they are not willing to use contraceptive again and $47.5 \%$ do not respond to the question. This implies that $47.5 \%$ of the respondents are not sure whether they would use the contraceptive in the future or not.

\section{Discussion, Conclusion and Recommendations.}

\subsection{Discussion}

The study revealed that most of the respondents were educated (that is, $40.67 \%$ and $55.32 \%$ ). The findings also shows that the age of the respondents at first birth was between 15 and 34 years, with the highest between $20-24$ years, which was $44.21 \%$, followed by $15-19$ years $(21.28 \%)$. This teenage pregnancy and motherhood is in consonance with what WHO (2020, p. 50-56) and NDHS (2019, p. 97-102) asserted that childbearing during adolescence is understood to have adverse social consequences, particularly regarding educational attainment, as women who become mothers in their teens are more likely to drop out of school. According to NDHS (2019, p. 97-102), 19\% of girls age 15-19 have begun childbearing; $14 \%$ have given birth, and 4\% are pregnant with their first child.

While assessing the knowledge of women of childbearing age concerning contraceptive implants, the study shows that $65.72 \%$ (278 women) had heard about contraceptive before while 34.28\% (145 women) have not heard it before. It was further revealed that $46.81 \%$ (198) got the information about contraceptive implants from the health facility during their visits. 52.48\% (222 women) knew that contraceptive implants have a lot of benefits while $47.52 \%$ (201 women) did not know if contraceptive 


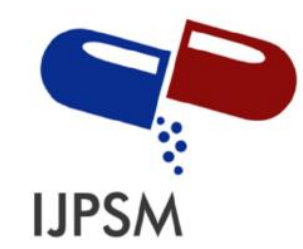

Paul Hassan Ilegbusi et al, Int. Journal of Pharmaceutical Sciences and Medicine (IJPSM), Vol.6 Issue. 6, June- 2021, pg. 64-97

ISSN: 2519-9889

Impact Factor: 3.426

implants have benefits. Also, the study shows that $20.33 \%$ ( 86 women) were aware of the minimal side effects of contraceptive implants while 79.67\% (337 women) were not aware. This indicates that some women were using contraceptive implants without knowing much about its side effects. Only 55.56\% (235 women) were aware of the safety of contraceptive implants while $44.44 \%$ (188 women) were not aware.

The study also shows that $46.57 \%$ (197 women) knew that contraceptive implants are highly effective while $53.19 \%$ ( 225 women) did not know the effectiveness. It was revealed that $7.57 \%$ (32 women) knew that fertility would be returned after the removal of contraceptive implants whereby $92.43 \%$ (391 women) did not know. These findings really show a knowledge gap in women of childbearing age in Akungba-Akoko towards the use of contraceptive implants. The findings in this study is in agreement with what Ajayi et al. (2018, p. 4-8) showed in their studies that women of childbearing age who were not using any form of contraceptive was as a result of lack of knowledge. Furthermore, Prateek \& Saurabh (2012, p. 416-420) asserted in their studies that some women lack knowledge about contraceptives, hence, they did not accept it.

This survey also measures the attitude of women of childbearing age towards the acceptance of contraceptive implants in Akungba-Akoko. The findings revealed that 39.7\% (168 women) thought that contraceptive implants are cost-effective method of family planning while $60.3 \%$ (255 women) did not think about it. The study also shows that $61.9 \%$ (262 women) thought that contraceptive implants bring harmony between couples while $38.1 \%$ ( 161 women) did not think of it.

This survey further reveals reasons some women are not interested in contraceptive implants; this include: fear of side effects (32.2\%); it diminishes sexual pleasure (19.1\%); it encourages promiscuity (16.8\%); lack of information (8.5\%); expectant of becoming pregnant $(8.3 \%)$; contraceptive failure (4.7\%); husband's refusal (4.5\%); lack of regular sex (3.3\%); and lack of interest $(2.6 \%)$. These findings are in agreement with the studies of Olugbenga-Bello et al. (2011), Prateek \& Saurabh (2012, p. 416-420), Abiodun \& Balogun (2009, p. 146-149), Alemayehu et al. (2012, p. 7), and Ajayi et al. (2018, p. 4-8) who reported in their various studies that women of childbearing age agreed to contraceptives being encouraging promiscuity; it diminishes sexual pleasure; some were afraid of the side effects; contraceptive failure; lack of interest; lack of regular sex; husband's refusal; and expectant of becoming pregnant.

The study also shows that $51.1 \%$ (216 women) thought that religion forbids the use of contraceptive implants while $48.9 \%$ (207 women) did not agree. This finding is against what Olugbenga-Bello et al. (2011) reported in their studies that contraceptives are not against religion. It shows that contraceptives acceptance varies accordingly in each communities based on their belief system. 


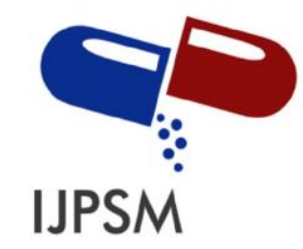

Paul Hassan Ilegbusi et al, Int. Journal of Pharmaceutical Sciences and Medicine (IJPSM), Vol.6 Issue. 6, June- 2021, pg. 64-97

ISSN: 2519-9889

Impact Factor: 3.426

Moreover, the findings reveals that $31.9 \%$ (135 women) thought that culture forbids the use of contraceptive implants while $68.1 \%$ (288 women) did not agree. This is in consonance with the assertion of Olugbenga-Bello et al. (2011) who reported that contraceptives are not against culture.

This study assessed the practice of women of childbearing age towards the acceptance of contraceptive implants in Akungba-Akoko. The study shows reasons for choosing contraceptive implants as follows: it is safe ( $30 \%$ of 278 women); it is highly effective ( $23.4 \%$ of 278 women); and it is convenient $(12.3 \%$ of 278 women). These findings are in agreement with what Alemayehu et al. (2012, p. 7) reported that the main reasons mentioned for switching to implant contraceptive among women of childbearing age were: convenience, contraceptive failure and experienced side effects with other contraceptive methods.

The findings from this study also reveals reasons women are not accepting contraceptive implants as follows: fear of side effects ( $12.5 \%$ of 145 women); lack of interest ( $10.9 \%$ of 145 women); husband's refusal ( $4 \%$ of 145 women); lack of information (1.9\% of 145 women); religion influence (1.7\% of 145 women); contraceptive failure (1.4\% of 145 women); lack of regular sex (1.2\% of 145 women); and it diminishes sexual pleasure ( $0.7 \%$ of 145 women). These findings are in consonance with the studies of Olugbenga-Bello et al. (2011), Prateek \& Saurabh (2012, p. 146-149), Abiodun \& Balogun (2009, p. 146-149) and Ajayi et al. (2018, p. 4-8) who stated that some women are are afraid of the side effects of contraceptives; it diminishes sexual pleasure; lack of interest; lack of regular sex; husband's refusal; and lack of knowledge.

This study also shows that $36.6 \%$ (155 out of 278 women) have been using contraceptive implants between $1-3$ years, $19.1 \%$ ( 81 out of 278 women) have been on contraceptive implants less than a year, whereby $9.9 \%$ (42 out of 278 women) have been using contraceptive implants for over three (3) years. This could be as a result of getting more information from the health facilities.

Furthermore, the findings reveal that out of the 145 women who are not using contraceptive implants, $14.9 \%$ (63 women) showed their interest in the future use of contraceptive implants, whereby $18.9 \%$ ( 80 women) declined in the future use of contraceptive implants. This decline could also be traced to lack of knowledge on the part of the women of childbearing age towards the acceptance of contraceptive implants in Akungba-Akoko.

The study shows that $50.8 \%$ ( 215 women) had experienced the side effects from contraceptive implants before while $48.5 \%$ ( 205 women) had never experienced any side effects from contraceptive implants. The findings also reveal that $34.3 \%$ (145 out of 213 women) showed their willingness to continue using contraceptive implants despite side effects while $18.2 \%$ (77 out of 213 women) declined of using contraceptive implants. 


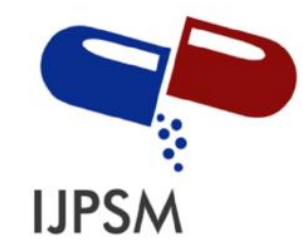

Paul Hassan Ilegbusi et al, Int. Journal of Pharmaceutical Sciences and Medicine (IJPSM), Vol.6 Issue. 6, June- 2021, pg. 64-97

ISSN: 2519-9889

Impact Factor: 3.426

Furthermore, the study showed that there is no significant association between the age of women of childbearing and the use of contraceptive implants. It implies that age does not have a significant influence or does not affect the use of contraceptive. This is in disparity with what Ejembi et al. (2015, p. 3-7), Kebede et al. (2019, p. 12-14) and Ajayi et al. (2018, p. 4-8) reported in their studies that the identified factors influencing the use of contraceptive use included age, parity and marital type.

However, there is a significant association between educational status and the current use of contraceptive implants. This finding is in consonance with the studies of Prateek \& Saurabh (2012, p. 416-420), Ajayi et al. (2018, p. 4-8), Ejembi et al. (2015, p. 3-7), and Nyarko (2015, p. 4) who reported that the level of education was significantly associated with ever use of any modern family planning method.

Similarly, there is a significant association between the age at first birth and the use of contraceptive implants. This is in consonance with the studies carried out by Prateek \& Saurabh (2012, p. 416-420), Ajayi et al. (2018, p. 4-8) and Kebede et al. (2019, p. 12-14) that showed that woman's number of children alive, age at marriage correlated with the uptake of modern family planning method.

\subsection{Conclusion}

Based on the findings from the study, it is concluded that the knowledge of women of childbearing age towards the acceptance of contraceptive implants needed to be improved upon. Women of reproductive age needed to be fully informed about the cost-effectiveness, benefits and minimal side effects of contraceptive implants. The study showed that most of the women who are currently using contraceptive implants did not know that fertility returns immediately after the removal of contraceptive implants.

The study has also revealed that the attitude of women of childbearing age towards the acceptance of contraceptive implants should be corrected.

Furthermore, the study revealed the reasons women of childbearing age are not interested in contraceptive implants as follows: fear of side effects; it diminishes sexual pleasure; it encourages promiscuity; lack of information; expectant of becoming pregnant; contraceptive failure; husband's refusal; and lack of interest.

In addition, the study revealed the reasons for choosing contraceptive implants by women of childbearing age as: it is safe; it is highly effective; and it is convenient.

The study also indicated factors influencing the acceptance of contraceptive implants among women of childbearing age as: fear of side effects; lack of interest; husband's refusal; lack of information; religion influence; contraceptive failure; lack of regular sex; and it diminishes sexual pleasure. 


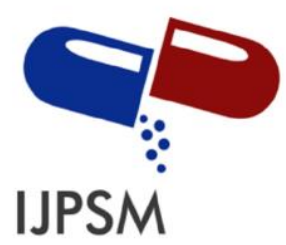

Paul Hassan Ilegbusi et al, Int. Journal of Pharmaceutical Sciences and Medicine (IJPSM), Vol.6 Issue. 6, June- 2021, pg. 64-97

ISSN: 2519-9889

Impact Factor: 3.426

The study also revealed that while some women had decided to continue using contraceptive implants in the future, some had declined in its use completely due to some of the side effects they had experienced before.

\subsection{Recommendations}

The findings of this study have revealed the knowledge gap, attitude and practice of women of childbearing age towards the acceptance of contraceptive implants in Akungba-Akoko. In a bid to improve the knowledge, attitude and practice of women of reproductive age towards the acceptance of contraceptive implants, the following are recommended:

- All health workers should intensify efforts by properly informing the women of childbearing age concerning contraceptive implants.

- During antenatal and postnatal visits, women should be health educated on the benefits, the cost-effectiveness and minimal side effects of contraceptive implants.

- There is the need for couples to understand each other and decide on the use of contraceptive implants, which is safe, convenient and highly effective for the family circuit.

- There should be more public enlightenment campaigns on the use of contraceptive implants most especially the sexually active teenagers, so as to prevent teenage pregnancies and teenage motherhood.

- Regular jingles should be on radio and television, so as to improve the knowledge of women of childbearing age towards the acceptance of contraceptive implants.

- The husbands should be carried along during family planning counselling before their wives choose any contraceptive implants.

- All myths, rumours and misconceptions against contraceptive implants should be dispelled by the government either through regular jingles or through the use of mass media and billboards.

- Contraceptive implants and its attendant services should be rendered free to all women of childbearing age in Nigeria so as to promote family planning.

Any woman with the side effects of contraceptive implants should be treated or managed freely in the health institutions in Nigeria.

\section{References}




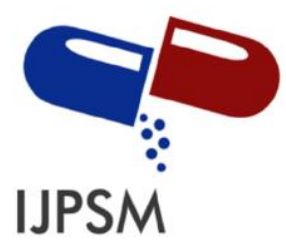

Paul Hassan Ilegbusi et al, Int. Journal of Pharmaceutical Sciences and Medicine (IJPSM), Vol.6 Issue. 6, June- 2021, pg. 64-97

ISSN: 2519-9889

Impact Factor: 3.426

[1]. Abiodun, O. M., \& Balogun, O. R. (2009). Sexual activity and contraceptive use among young female students of tertiary educational institutions in Ilorin, Nigeria. Contraception, 79(2), 146-149. Retrieved on 20th December, 2020 from https://doi.org/10.1016/j.contraception.2008.08.002

[2]. Ajayi, A. I., Adeniyi, O. V., \& Akpan, W. (2018). Maternal health care visits as predictors of contraceptive use among childbearing women in a medically underserved state in Nigeria. Journal of health, population, and nutrition, 37(1), 19. Retrieved on 20th December, 2020 from https://doi.org/10.1186/s41043-018-0150-4

[3]. Alemayehu, M., Belachew, T., \& Tilahun, T. (2012). Factors associated with utilization of long acting and permanent contraceptive methods among married women of reproductive age in Mekelle town, Tigray region, north Ethiopia. BMC pregnancy and childbirth, 12(6). Retrieved on 20th December, 2020 from https://doi.org/10.1186/1471-2393-12-6

[4]. Ali, M., Akin, A., Bahamondes, L., Brache, V., Habib, N., Landoulsi, S., Hubacher, D., \& WHO study group on subdermal contraceptive implants for women. (2016). Extended use up to 5 years of the etonogestrel-releasing subdermal contraceptive implant: comparison to levonorgestrel-releasing subdermal implant. Human reproduction (Oxford, England), 31(11), 2491-2498. Retrieved on 20th December, 2020 from https://doi.org/10.1093/humrep/dew222

[5]. Bandura, A. (1977). Self-efficacy: Toward a unifying theory of behavioral change. Psychological review, 84(2), 191-215. Retrieved on 20th December, 2020 from https://doi.org/10.1037/0033-295X.84.2.191

[6]. Bongaarts, J., \& Bruce, J. (1995). The causes of unmet need for contraception and the social content of services. Studies in family planning, 26(2), 57-75.

[7]. Campbell, D.T., \& Stanley, J.C. (1963). EXPERIMENTAL AND QUASI-EXPERIMENTAL DESIGNS FOR RESEARCH. (1ed.). Houghton Mifflin Company.

[8]. Charyeva, Z., Oguntunde, O., Orobaton, N., Otolorin, E., Inuwa, F., Alalade, O., Abegunde, D., \& Danladi, S. (2015). Task Shifting Provision of Contraceptive Implants to Community Health Extension Workers: Results of Operations Research in Northern Nigeria. Global health, science and practice, 3(3), 382-394. Retrieved on 20th December, 2020 from https://doi.org/10.9745/GHSP-D-15-00129

[9]. Coukell, A. J., \& Balfour, J. A. (1998). Levonorgestrel subdermal implants. A review of contraceptive efficacy and acceptability. Drugs, 55(6), 861-887. Retrieved on 20th December, 2020 from https://doi.org/10.2165/00003495-199855060-00019

[10]. Creanga, A. A., Gillespie, D., Karklins, S., \& Tsui, A. O. (2011). Low use of contraception among poor women in Africa: an equity issue. Bulletin of the World Health Organization, 89(4), 258-266. Retrieved on 20th December, 2020 from https://doi.org/10.2471/BLT.10.083329

[11]. Ehinmowo, A.A., \& Eludoyin, O.M. (2010). The University as a nucleus for growth pole: Example from Akungba-Akoko, Southwest, Nigeria. International journal of sociology and (c) 2021, IJPSM All Rights Reserved, www.ijpsm.com 


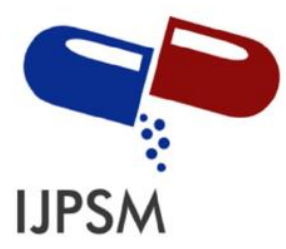

Paul Hassan Ilegbusi et al, Int. Journal of Pharmaceutical Sciences and Medicine (IJPSM), Vol.6 Issue. 6, June- 2021, pg. 64-97

ISSN: 2519-9889

Impact Factor: 3.426

anthropology, 2(7), 149-154. Retrieved on 4th January, 2021 from https://academicjournals.org/article/article1379428966 Ehinmowo\%20and\%20Eludoyin.pdf

[12]. Eisenberg, D.L., Secura, G.M., Madden, T.E., Allsworth, J.E., Zhao, Q., \& Peipert, J.F.(2012). Knowledge of contraceptive effectiveness. American journal of obstetrics and gynecology, 206(6), 479.e1-479.e4799. Retrieved on 20th December, 2020 from https://doi.org/10.1016/j.ajog.2012.04.012

[13]. Ejembi, C.L., Tukur, D., \& Aliyu, A.A. (2015). Contextual Factors Influencing Modern Contraceptive Use in Nigeria. Demographic and Health Surveys Program \& ICF International: Abuja \& Rockville.

[14]. Festin, M.P.R. (2020). Overview of modern contraception. Best practice \& research clinical obstetrics and gyaenecology, 66(2020), 4-14. Retrieved on 20th December, 2020 from https://doi.org/10.1016/j.bpobgyn.2020.03.004

[15]. French, V., \& Darney, P. (2015). Implantable Contraception. The Global Library of Women's Medicine. Retrieved on 20th December, 2020 from https://doi.org/10.3843/GLOWM.10399

[16]. Ghulam, M., Syed, K.A., Waqas, H., Safdar, A., Muhammad, I., Wajahat, H., Aftab, A., Erik, M. (2015). Family Planning Knowledge, Attitudes, and Practices among Married Men and Women in Rural Areas of Pakistan: Findings from a Qualitative Need Assessment Study. International journal of reproductive medicine, 2015(190520). Retrieved on 20th December, 2020 from https://dx.doi.org/10.1155/2015/190520

[17]. Gubhaju, B. (2009). The influence of wives' and husbands' education levels on contraceptive method choice in Nepal, 1996-2006. International perspectives on sexual and reproductive health, 35(4), 176-185. Retrieved on 20th December, 2020 from https://doi.org/10.1363/ipsrh.35.176.09

[18]. Hall, K.S. (2012). The Health Belief Model can guide modern contraceptive behavior research and practice. Journal of midwifery \& women's health, 57(1), 74-81. Retrieved on 31st December, 2020 from https://doi.org/10.1111/j.1542-2011.2011.00110.x

[19]. Haugen, M. M., Evans, C. B., \& Kim, M. H. (1996). Patient satisfaction with a levonorgestrel-releasing contraceptive implant. Reasons for and patterns of removal. The journal of reproductive medicine, 41(11), 849-854.

[20]. He, K., Dalton, V. K., Zochowski, M. K., \& Hall, K. S. (2017). Women's Contraceptive Preference-Use Mismatch. Journal of women's health, 26(6), 692-701. Retrieved on 20th December, 2020 from https://doi.org/10.1089/jwh.2016.5807

[21]. Hohmann, H., \& Creinin, M. D. (2007). The contraceptive implant. Clinical obstetrics and gynecology, 50(4), 907-917. Retrieved on 20th December, 2020 from https://doi.org/10.1097/GRF.0b013e318159c2f6

[22]. Holborn, M., \& Haralambos, M. (2009). Haralambos and Holborn - Sociology Themes and Perspectives Student Handbook: AS and A2 level. (7ed.). Harper Collins. 


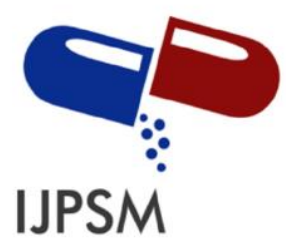

Paul Hassan Ilegbusi et al, Int. Journal of Pharmaceutical Sciences and Medicine (IJPSM), Vol.6 Issue. 6, June- 2021, pg. 64-97

ISSN: 2519-9889

Impact Factor: 3.426

[23]. Isley, M. M., \& Edelman, A. (2007). Contraceptive implants: an overview and update. Obstetrics and gynecology clinics of North America, 34(1), 73-ix. Retrieved on 20th December, 2020 from https://doi.org/10.1016/j.ogc.2007.01.002

[24]. Jacobson, J. L. (2000). Transforming family planning programmes: towards a framework for advancing the reproductive rights agenda. Reproductive health matters, 8(15), 21-32. Retrieved on 20th December, 2020 from https://doi.org/10.1016/s0968-8080(00)90003-X

[25]. Jacobstein, R. (2018). Liftoff: The Blossoming of Contraceptive Implant Use in Africa. Global health, science and practice, 6(1), 17-39. Retrieved on 20th December, 2020 from https://doi.org/10.9745/GHSP-D-17-00396

[26]. Kavanaugh, M.L. \& Anderson, R.M. (2013). Contraception and Beyond: The Health Benefits of Services Provided at Family Planning Centers, New York: Guttmacher Institute. Retrieved on 20th December, 2020 from <http://www.guttmacher.org/ pubs/health-benefits.pdf>

[27]. Kebede, A., Abaya, S.G., Merdassa, E., \& Bekuma, T.T. (2019). Factors affecting demand for modern contraceptives among currently married reproductive age women in rural Kebeles of Nunu Kumba district, Oromia, Ethiopia. Contraception and reproductive $\begin{array}{llll}\text { medicine, } 4(21) . \quad \text { Retrieved } & \text { on } 2020\end{array}$ from https://doi.org/10.1186/s40834-019-0103-3

[28]. Kolawole, O.O., Sowemimo, O.O., Ojo, O.O., \& Fasubaa, O.B. (2018). Contraceptive implants: A review and current perspective in Southwest Nigeria. Tropical journal of obstetrics and gynaecology, 35(2), 108-112.

[29]. Ladipo, O., \& Coutinho, E. M. (1994). Contraceptive implants. Current opinion in obstetrics \& gynecology, 6(6), 564-569.

[30]. Marshall, J. \& Raynor, M. (2014). Myles Textbook for Midwives. (16ed.). Churchill Livingstone.

[31]. Mavranezouli, I. (2008). The cost-effectiveness of long-acting reversible contraceptive methods in the UK: analysis based on a decision-analytic model developed for a National Institute for Health and Clinical Excellence (NICE) clinical practice guideline. Human reproduction, 23(2008), 1338-45.

[32]. McDonald-Mosley, R., Burke, A.E. (2010). Contraceptive implants. Semin Reprod Med. 2010 Mar;28(2):110-117. Retrieved on 31st December, 2020 from https://doi.org/10.1055/s-0030-1248135

[33]. Mkangi, G.C., \& Parkin, D. (1983). The Social Cost of Small Families \& Land Reform: A Case Study of the Wataita of Kenya. (1ed.). Pergamon.

[34]. National Population Commission (NPC) [Nigeria] \& ICF. (2019). Nigeria Demographic and Health Survey 2018. Abuja and Rockville: NPC and ICF. 


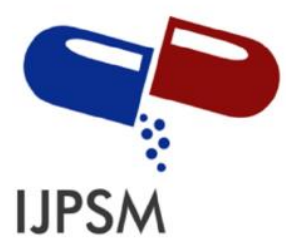

Paul Hassan Ilegbusi et al, Int. Journal of Pharmaceutical Sciences and Medicine (IJPSM), Vol.6 Issue. 6, June- 2021, pg. 64-97

ISSN: 2519-9889

Impact Factor: 3.426

[35]. Nyarko, S. H. (2015). Prevalence and correlates of contraceptive use among female adolescents in Ghana. BMC women's health, 15(60), 2015. Retrieved on 20th December, 2020 from https://doi.org/10.1186/s12905-015-0221-2

[36]. Odimegwu, C.O. (1999). Family Planning Attitudes and Use in Nigeria: A Factor Analysis. International family planning perspectives, 25(2): 86-91.

[37]. Olugbenga-Bello, A.I., Abodunrin, O.L., \& Adeomi, A.A. (2011). Contraceptive practices among women in Rural Communities in South-Western Nigeria. Global journal of medical research, 11(2). Retrieved on 20th December, 2020 from https://www.medicalresearchjournal.org/index.php/GJMR/article/view/76

[38]. Onwujekwe, O. E., Enemuoh, J. C., Ogbonna, C., Mbachu, C., Uzochukwu, B. S., Lawson, A., \& Ndyanabangi, B. (2013). Are modern contraceptives acceptable to people and where do they source them from across Nigeria?. BMC international health and human rights, 13(7). Retrieved on 20th December, 2020 from https://doi.org/10.1186/1472-698X-13-7

[39]. Orji, E. O., \& Onwudiegwu, U. (2002). Prevalence and determinants of contraceptive practice in a defined Nigerian population. Journal of obstetrics and gynaecology: the journal of the Institute of Obstetrics and Gynaecology, 22(5), 540-543. Retrieved on 31st December, 2020 from https://doi.org/10.1080/0144361021000003126

[40]. Oye-Adeniran, B. A., Adewole, I. F., Odeyemi, K. A., Ekanem, E. E., \& Umoh, A. V. (2005). Contraceptive prevalence among young women in Nigeria. Journal of obstetrics and gynaecology : the journal of the Institute of Obstetrics and Gynaecology, 25(2), 182-185. Retrieved on 20th December, 2020 from https://doi.org/10.1080/01443610500041156

[41]. Oye-Adeniran, B. A., Adewole, I. F., Umoh, A. V., Oladokun, A., Ghadegsin, A., Ekanem, E. E., Yusuf, B., Odeyemi, K. A., Iwere, N., \& Mahmoud, P. (2006). Community-based study of contraceptive behaviour in Nigeria. African journal of reproductive health, 10(2), 90-104.

[42]. Peralta, O., Diaz, S., \& Croxatto, H. (1995). Subdermal contraceptive implants. The journal of steroid biochemistry and molecular biology, 53(1-6), 223-226. Retrieved on 20th December, 2020 from https://doi.org/10.1016/0960-0760(95)00051-Z

[43]. Pillitteri, A. (2010). Maternal \& Child Health Nursing: Care of the Childbearing \& Childbearing Family (6th ed.). : Lippincort Williams \& Wilkins.

[44]. Population Reference Bureau. (2019). Family Planning Data Sheet 2019. Retrieved 29th December, 2020 from https://www.prb.org/fpdata.

[45]. Prateek, S. S., \& Saurabh, R. S. (2012). Contraceptive practices adopted by women attending an urban health centre. African health sciences, 12(4), 416-421. Retrieved on 20th December, 2020 from https://doi.org/10.4314/ahs.v12i4.3

[46]. Rowlands, S., Searle, S. (2014). Contraceptive implants: current perspectives. Open access journal contraception. 2014(5), 73-84. Retrieved on 20th December, 2020 from https://doi.org/10.2147/OAJC.S55968 


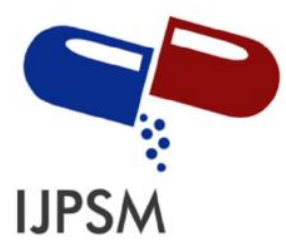

Paul Hassan Ilegbusi et al, Int. Journal of Pharmaceutical Sciences and Medicine (IJPSM), Vol.6 Issue. 6, June- 2021, pg. 64-97

ISSN: 2519-9889

Impact Factor: 3.426

[47]. Sensoy, N., Korkut, Y., Akturan, S., Yilmaz, M., Tuz, C., \& Tuncel, B. (2018). Factors Affecting the Attitudes of Women toward Family Planning. Retrieved on 20th December, 2020 from https://www.intechopen.com/books/family-planning/factors-affecting-the-attitudes-of-womentoward-family-planning

[48]. Sivin, I. (2003). Risks and benefits, advantages and disadvantages of levonorgestrel-releasing contraceptive implants. Drug safety, 26(5), 303-335. Retrieved on 20th December, 2020 from https://doi.org/10.2165/00002018-200326050-00002

[49]. Thomas, L. (2019). Advantages and Disadvantages of the Contraceptive Implant. Retrieved on 30th December, 2020 from https://www.news-medical.net/health/Advantages-and-Disadvantages-of-the-Contraceptive-I mplant.aspx

[50]. Tawiah, E. O. (1997). Factors affecting contraceptive use in Ghana. Journal of biosocial science, 29(2), 141-149. Retrieved on 20th December, 2020 from https://doi.org/10.1017/s0021932097001417

[51]. Tolley, E., Loza, S., Kafafi, L., \& Cummings, S. (2005). The impact of menstrual side effects on contraceptive discontinuation: findings from a longitudinal study in Cairo, Egypt. International family planning perspectives, 31(1), 15-23. Retrieved on 20th December, 2020 from https://doi.org/10.1363/3101505

[52]. United Nations Population Fund. (2016). Universal Access to Reproductive Health: Progress and Challenges. (2016ed.). New York. UNFPA.

[53]. Usman, S.O., Kalejaye, O.O., Isola, I.N., Oluwaniyi, O., Ojogbede, A.K. \& Adu, A.S. (2016). Family planning practices among rural community women in Nigeria. Journal of Experimental and Integrative Medicine, 6(2), 88. Retrieved on 20th December, 2020 from https://www.researchgate.net/publication/307898463_Family_planning_practices_among_rur al_community_women_in_Nigeria

[54]. Ward, S.L. \& Hisley, S.M. (2009). Maternal-Child Nursing Care Optimizing Outcomes for Mothers, Children, and Families.: F.A. Davis Company.

[55]. World Health Organization. (1985). Facts about an implantable contraceptive: memorandum from a WHO meeting. (1985). Bulletin of the World Health Organization, 63(3), 485-494.

[56]. World Health Organization. (2020). World health statistics 2020 monitoring health for the SDGs sustainable development goals. Geneva: World Health Organization.

[57]. World Health Organization. (2017). WHO Model List of Essential Medicines. (20ed.). Geneva: World Health Organization.

[58]. World Health Organization \& John's Hopkins Bloomberg School of Public Health/Center for Communication Programs. (2018). Family Planning: A Global Handbook for Providers (3ed.). : WHO \& CCP. 


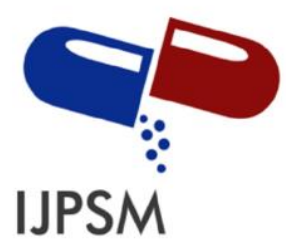

Paul Hassan Ilegbusi et al, Int. Journal of Pharmaceutical Sciences and Medicine (IJPSM), Vol.6 Issue. 6, June- 2021, pg. 64-97

ISSN: 2519-9889

Impact Factor: 3.426

[59]. Yourdictionary. (2020). Family Planning meaning. Yourdictionary.com. Retrieved on 20th December, 2020 from https://www.yourdictionary.com/family-planning

\section{A Brief Authors' Biography}

Ilegbusi, Paul Hassan is from Oka-Akoko, Ondo State, Nigeria. He has Advanced Diploma in Primary Health Care Education (Federal Training Centre For Teachers of Health Sciences, UCH, Ibadan, Nigeria, 2011); Higher Diploma in Community Health (UCH, Ibadan, Nigeria, 2008); Advanced Certificate in Health Administration and Management (UCH, Ibadan, Nigeria, 2012); Certificate in Computer Appreciation (UCH, Ibadan, Nigeria, 2012); Certificate in Community Health (1996); Certificate in Family Planning Motivation (1996). Ilegbusi is a Senior Lecturer in Community Health Department, Ondo State College of Health Technology, Akure, Nigeria. He is a Chief Community Health Officer. He has been working as a Community Health Practitioner in Nigeria for over 24 years in Nigeria. He is an Examiner for National Qualifying Examinations for Community Health students in Nigeria since 2016. He has participated in many national and international workshops relating to Community Health and Public Health. He is a researcher in Public Health. He is married to 'Adunola with three godly children. 